\title{
THERMAL INSULATION MATERIALS BASED ON FLAX STRAW
}

\author{
Department of Building Production, \\ Lviv Polytechnic National University \\ oksana.r.pozniak@lpnu.ua
}

(C) Novosad P., Pozniak O., 2021

The development of plant-based materials will help to solve the problems associated with the use of agricultural waste, and at the same time to get inexpensive and effective insulation materials based on environmentally friendly local raw materials. The advantages of such materials are availability, fast recovery, low cost, environmental friendliness and low thermal conductivity. In the work with the use of flax straw at a consumption of Portland cement of $150 \mathrm{~kg}$ per $1 \mathrm{~m}^{3}$ of concrete, thermal insulation lightweight concrete with an average density of $350 \mathrm{~kg} / \mathrm{m}^{3}$ and a strength of $0.53 \mathrm{MPa}$ was obtained. The article presents the results of research of temperature changes on the surface of external enclosing structures using the developed thermal insulation concrete based on flax straw in combination with a solar energy absorber. It is established that such a structure of an external wall provides thermal inertia of a protection within 7-7.5 hours.

Key words: energy efficiency, energy saving, flax straw, thermal insulation concrete, adsorber, thermal inertia.

\section{Problem statement}

At this time, due to the rapid rise of energy prices, the issue of improving the energy efficiency of residential and industrial buildings and structures arises. One of the ways to increase energy efficiency is the use of modern thermal insulation materials. Thermal insulation materials are a primary element of construction, designed not only for residential premises, office buildings, hotels, but also for industrial facilities. Rising energy prices in Ukraine are forcing more and more households to invest in energy saving houses, apartments and other premises. The market of thermal insulation materials in Ukraine will continue to show positive growth rates, the main factors that will affect this market include: growth of the real estate market, the level of purchasing power, developed by the State Agency for Energy Efficiency and implemented Government program "warm loans". Thermal insulation with mineral wool, glass wool or expanded polystyrene is the most effective way of thermal insulation, but also the most expensive. The development of plant-based materials will help solve the problems associated with the use of agricultural waste, and at the same time obtain inexpensive and effective insulation materials based on environmentally friendly and quickly renewable local raw materials (Sanytsky, 2013; Babenko, 2018).

\section{Relevance of research}

The use of any type of insulation saves energy during operation, but this does not mean that they all meet the principles of sustainable development in construction. The impact of the production of thermal insulation materials and the use of resources on the environment and health, which affects their environmental friendliness, should not be underestimated (Perry, 2019). Plant materials have a number of advantages, such as availability, rapid recovery, low cost, environmental friendliness and low thermal conductivity, along with the ability to use both organic and inorganic binders. 
Therefore, the development of thermal insulation materials using vegetable raw materials is an urgent task of modern construction production. The obtained materials meet the requirements of sustainable development, energy efficiency, economic efficiency and environmental compatibility. Cellulose insulation materials are the most environmentally friendly raw materials used in construction. During growth, plant raw materials absorb carbon dioxide and retain it in the insulating material during operation. Therefore, the development of thermal insulation materials using vegetable raw materials is an urgent task of modern construction production.

\section{Analysis of recent research and publications}

The process a concrete production and other building materials requires a large amount of energy. During this process, a large amount of greenhouse gases are formed, especially carbon dioxide $\left(\mathrm{CO}_{2}\right)$. One idea is to replace some building materials with plant-based materials to reduce $\mathrm{CO}_{2}$ levels. Based on the need, new concepts in building materials that offer the combined benefits of energy efficiency and thermal comfort are likely to gain momentum in the construction industry (Garikapati, 2020). Natural fibers, in particular flax, hemp, etc., can be used as reinforcement for building materials (Walker, 2014; Rahim, 2016; Collet, 2017; Novosad, 2019). Biologically based materials are increasingly recommended because they have a low impact on the environment and are ideal for buildings with a high quality environment. The results of research (Rahim, 2015) showed that biologically based materials have high hygienic properties. It is well-known that a flax is a traditional for Ukraine bast technical culture, which is planted in many regions of our country (especially in the North-West region). Flax products are used for the manufacturing of various goods for different purposes. One of the ways of efficient use of flax waste and production of products with high consumer qualities is the production of construction and thermal insulation materials from the flax straw (Pushkar, 2012). Due to the complex and porous microstructure of flax, materials with its content are characterized by good hydraulic and thermal behavior, allows to classify flax as an excellent regulator of humidity (Benmahiddine, 2020; Asli, 2021). Flax concrete with a mass content of $14.5 \%$ of flax fibers with an average compressive strength of $0.8 \mathrm{MPa}$ is used as an insulating and filling material in buildings. The authors (Boghossiana, 2008) found that based on the number of cracks, the total crack area and the maximum crack width formed during the first 24 hours after the formation and exposure to hot, dry and windy conditions, flax fibers were somewhat more effective in controlling restrained plastic shrinkage cracking. than commercially available polypropylene and glass fibers for the investigated mortar mixture. Analysis of the work (Page, 2017) showed the feasibility of using a mixture of hemp and flax. The composite material is characterized by increased strength due to increased density, as well as lower shrinkage.

The aim of this work is to study the influence of flax straw on the properties of heat insulating lightweight concretes.

\section{Materials and Methods}

To conduct the study, the Portland cement CEM I 42,5 R produced at PJSC "Ivano-Frankivsk cement" (Yamnytsa, Ivano-Frankivsk region, Ukraine) with specific surface of $347 \mathrm{~m}^{2} / \mathrm{kg}$, the retaining on sieve № 008 is $0.5 \%$, the initial setting time is 1 hour $20 \mathrm{~min}$, the final setting time is 5 hours $20 \mathrm{~min}$ was used. Natural sand (fineness modulus of 1.4-1.5) and fly ash (FA) from the Burshtyn TPP were used for aerated concrete production as a finely dispersed filler. Fly ash from Burshtynska thermal power plant had the following properties: true density $-2.22 \mathrm{~g} / \mathrm{cm}^{3}$; bulk density $-870 \mathrm{~kg} / \mathrm{m}^{3}$; retaining on sieve № 008 - 8.6 mass.\%; chemical composition, \% by mass: $\mathrm{SiO}_{2}-54 ; \mathrm{Al}_{2} \mathrm{O}_{3}-23.75 ; \mathrm{Fe}_{2} \mathrm{O}_{3}+\mathrm{FeO}-13.8$; $\mathrm{MgO}-1.91 ; \mathrm{CaO}-4.98 ; \mathrm{SO}_{3}-0.53 ; \mathrm{K}_{2} \mathrm{O}+\mathrm{Na}_{2} \mathrm{O}-0.25$. Flax straw was used as an organic filler. The organic filler exhibits low density (roughly $110 \mathrm{~kg} / \mathrm{m}^{3}$ ) and high porosity (approximately 70-75).

The flax straw reinforced concrete is a lightweight concrete with an organic filler. The flax straw represents lignified parts of flax stems, crushed during primary processing (Fig. 1). It accounts for $60-70 \%$ of 
the mass of processed flax stems. The flax straw consists of particles 10-20 mm in length and 0.1-1.5 mm thick, contains $45-58 \%$ cellulose, 21-29\% lignin and 23-26\% pentosans. The flax straw lightweight concrete consists of flax straw, binder - cement or lime, sand, water and, if it is necessary, a hardening accelerator. Flax fibres contain a large amount of $\mathrm{SiO}_{2}$ (silicon dioxide), which upon interaction with water and binder, due to hydration forms a strong connection of particles in the product. Reinforced concrete blocks or walls continue to gain strength over time.
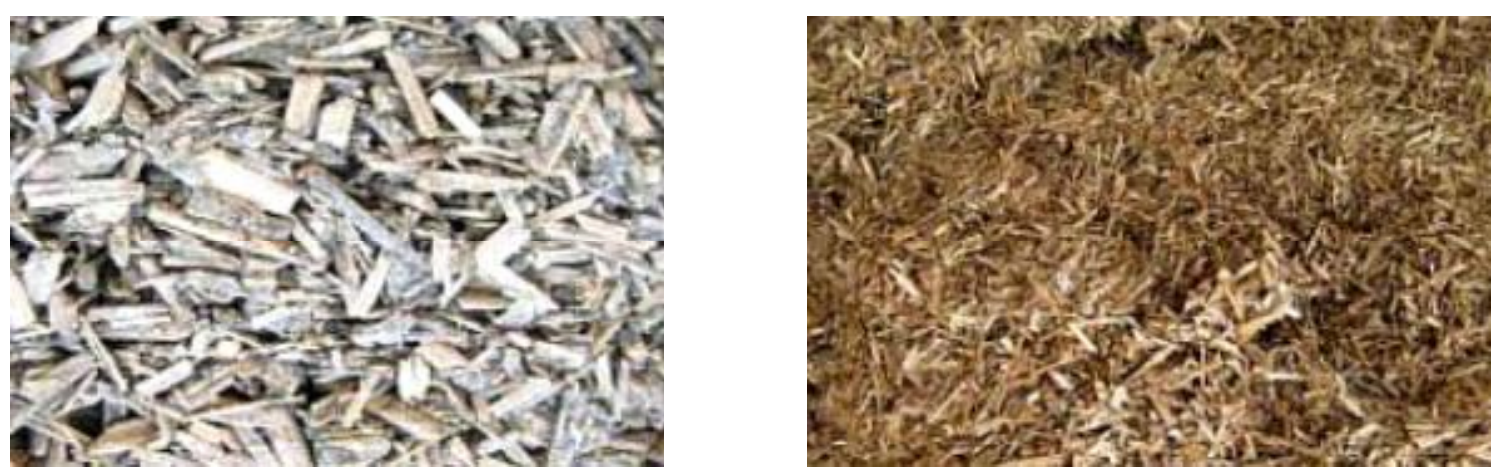

Fig. 1. Flax straw of different fractions

In this work, the compositions containing flax straw as a filler, as well as compositions, where the part of the flax straw was replaced by the fly ash and quartz sand in obtaining a heat insulating lightweight concrete were investigated. For this purpose samples of size $100 \times 100 \times 100 \mathrm{~mm}$ were moulded. The properties of specimens were determined after 28 days of curing. The density and compressive strength were carried out according to national standards.

\section{Results and Discussion}

The properties of light thermal insulation concrete with flax straw were studied. The flax straw was mixed with sand to prepare the samples. Then this mixture was filled with cement paste and mixed until a homogeneous mass. By changing the consumption of cement from 150 to $250 \mathrm{~kg}$ per $1 \mathrm{~m}^{3}$ of concrete at a mass ratio of cement: flax straw 1:0.9, the average density and strength of insulating lightweight concrete can be adjusted (Fig. 2).

Thus, at a consumption of Portland cement of $150 \mathrm{~kg}$ per $1 \mathrm{~m}^{3}$ of concrete, the average density of lightweight concrete is $350 \mathrm{~kg} / \mathrm{m}^{3}$, strength $-0.53 \mathrm{MPa}$, the calculated thermal conductivity is $0.09 \mathrm{~W} /(\mathrm{m} \mathrm{K})$. Naturally, increasing the consumption of cement provides an increase in the average density and strength of lightweight concrete.

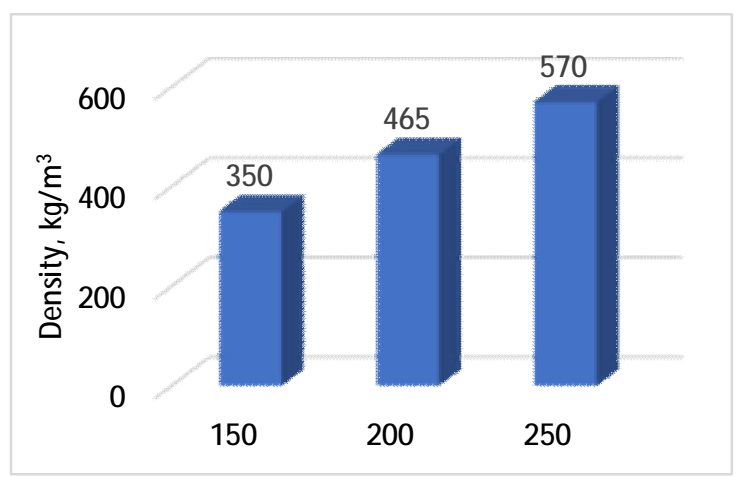

$a$

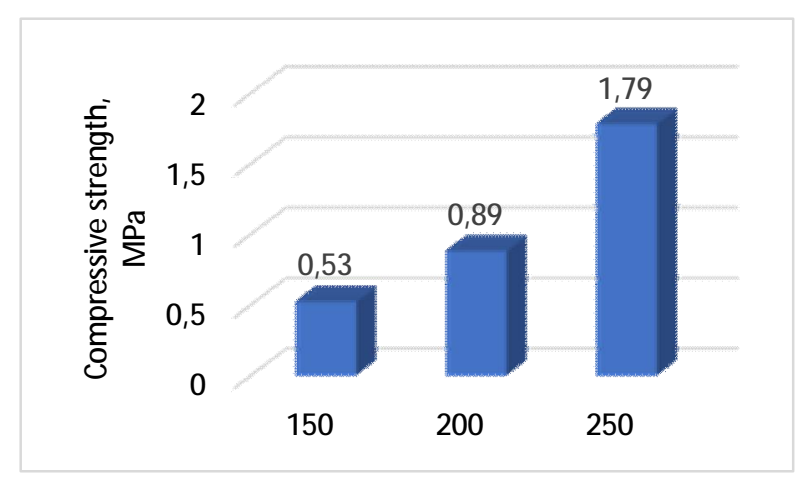

$b$

Fig. 2. The effect of cement consumption on the average density (a) and strength $(b)$ of lightweight concrete 
Rising gas and electricity prices are forcing more attention to energy-efficient housing, which allows the use of alternative heating systems. One of such options of effective alternative heat supply is the use of natural thermal insulation materials in combination with solar heat receivers, in particular with a glazed absorber. This allows to use the energy of the Sun: the sun's rays pass freely through the glass, fall on the absorber and heat it. The efficiency of such modern absorbers reaches $90 \%$, which allows to use solar energy in winter. At the same time, it should be noted that in December and January, with a shortage of solar energy, the efficiency of such a structure may decrease slightly. The developed material is used for the construction of a insulated wall which consists of a thermal insulation layer on the basis of a flax straw applied on a brick wall. A glazed wooden frame with an absorber, which intensively accumulates solar heat, is placed on top of the thermal insulation layer (Fig. 3).
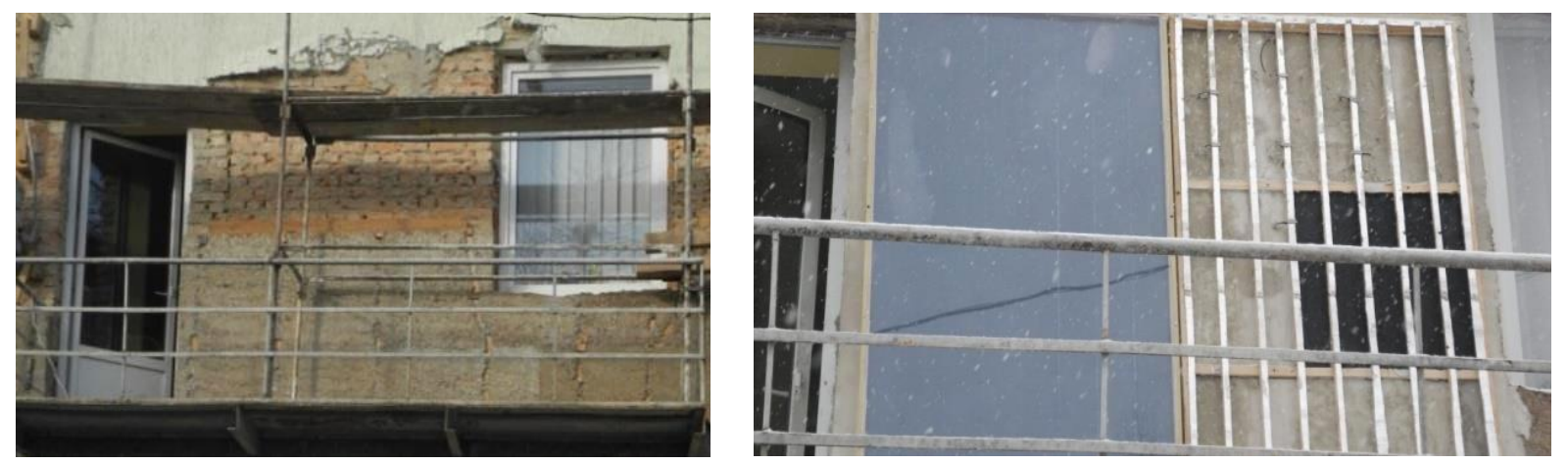

Fig. 3. Installation of thermal insulation material and absorber

The study of temperature changes on the surface of the thermal insulation layer fixed under the absorber and on the surface of the enclosing structure inside the room showed (Fig. 4) that the use of natural thermal insulation material with an average density of $350 \mathrm{~kg} / \mathrm{m}^{3}$ allows to accumulate the solar heat, which cannot be achieved by using traditional synthetic organic thermal insulation materials with an average density of $20-50 \mathrm{~kg} / \mathrm{m}^{3}$, such as polystyrene foam.

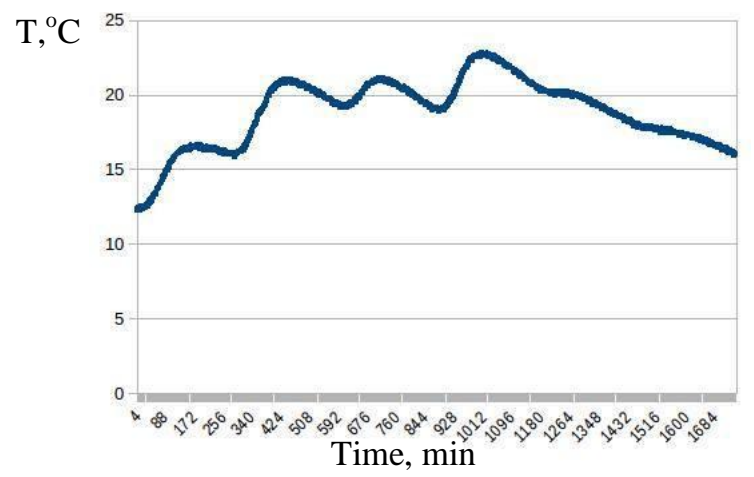

$a$

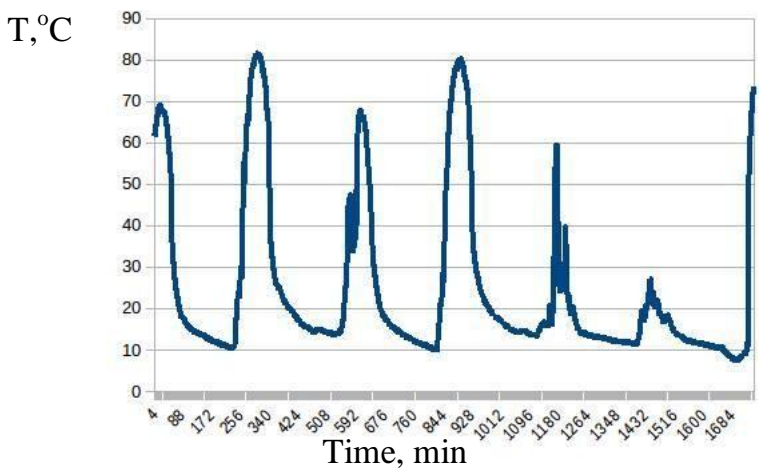

$b$

Fig. 4. The temperature on the inner surface of the brick wall (a) and thermal insulation material under the absorber $(b)$

In addition, the accumulated heat is evenly distributed in the volume of natural insulation material and actively counteracts the penetration of winter cold and summer heat into the house. Due to open pores the thermal insulation material on the basis of a flax fire is characterized by good vapor permeability that provides comfortable conditions of a microclimate indoors.

The temperature change on the surfaces of the absorber, thermal insulation material and the inner surface of the outer wall was recorded by temperature sensors. When the sun appears, the temperature of 


\section{Petro Novosad, Oksana Pozniak}

the absorber increases from 10 to $90{ }^{\circ} \mathrm{C}$, on the surface of the insulating material the temperature is $80{ }^{\circ} \mathrm{C}$, and on the surface of the wall inside the room $-20-22{ }^{\circ} \mathrm{C}$. Due to the heat capacity of the insulating material, additional protection of the enclosing structure is created, the accumulated heat in the layer of insulating material increases the thermal inertness of the wall.

The absorber intensively heats the surface of the thermal insulation layer, which allows to block the thermal radiation of the brick wall. On a clear sunny day, enough energy can be accumulated to compensate the heat loss of the house. It has been experimentally established that a $15 \mathrm{~cm}$ thick thermal insulation layer provides a stable thermal regime in the room for 7-7.5 hours due to the accumulated heat.

\section{Conclusions}

The use of domestic scientific, technical and technological achievements with the maximum involvement of the local component will contribute to the innovative development of the economy, scientific and educational potential, reducing dependence on the import of resources. Reducing the energy intensity of construction and operation of housing will help to increase the economic, energy and environmental safety of the country.

\section{References}

Sanytsky, M., Poznyak, O., Marushchak, U. (2013). Energy-saving technologies in construction. Lviv: Lviv Polytechnic Publishing House. [in Ukrainian].

Babenko, M., Estokova, A., Savytskyi, M., Unčík, S. (2018). Study of Thermal Properties of Lightweight Insulation Made of Flax Straw. Slovak Journal of Civil Engineering, 26 (2), 9-14. doi:10.2478/sjce-2018-008.

Perry, G. A. (2019) Mineral Wool Insulation is Not Green, Sustainable or Environmentally Friendly. Retrieved from https://miscimages-2.s3.amazonaws.com.

Garikapati, K. P., Sadeghian, P. (2020). Mechanical behavior of flax-lime concrete blocks made of waste flax shives and lime binder reinforced with jute fabric. Journal of Building Engineering, 20, 101187. doi:10.1016/j.jobe.2020.101187.

Walker, R., Pavia, S., Mitchell, R. (2014). Mechanical properties and durability of hemp-lime concretes. Construction and Building Materials, 61 (30), 340-348. doi:10.1016/j.conbuildmat.2014.02.065

Rahim, M., Douzane, O., Tran Le, A.D., Promis, G., Langlet T. (2016). Characterization and comparison of hygric properties of rape straw concrete and hemp concrete. Construction and Building Materials, 102 (1,15), 679687. doi:10.1016/j.conbuildmat.2015.11.021.

Collet, F., Prétot, S., Lanos, C. (2017). Hemp-Straw Composites: Thermal And Hygric Performances. Energy Procedia, 139, 294-300. doi:10.1016/j.egypro.2017.11.211.

Novosad, P., Poznyak, O., Melnyk, V., Braichenko, S. (2019). Porous Thermal Insulation Materials on Organic and Mineral Fillers. In: Blikharskyy Z., Koszelnik P., Mesaros P. (eds) Proceedings of CEE 2019. CEE 2019. Lecture Notes in Civil Engineering, vol 47. Springer, Cham. doi:10.1007/978-3-030-27011-7_45.

Rahim, M., Douzane, O., Tran Le, A. D., Promis, G., Laidoudi, B., Crigny A., Dupre, B., Langlet, T. (2015). Characterization of flax lime and hemp lime concretes: Hygric properties and moisture buffer capacity. Energy and Buildings, 88, 91-99. doi:10.1016/j.enbuild.2014.11.043.

Pushkar, G. O., Semak, B. D. (2012). Using linen fiber for forming interior textile range. Bulletin of the Kyiv National University of Technologies and Design, 2, 91-97. (in Ukranian).

Benmahiddine, F., Cherif, R., Bennai, F., Belarbi, R. (2020). Effect of flax shives content and size on the hygrothermal and mechanical properties of flax concrete. Construction and Building Materials 262:120077. doi:10.1016/j.conbuildmat.2020.120077.

Asli, M., Brachelet, F., Sassine, E., Antczak, E. (2021). Thermal and hygroscopic study of hemp concrete in real ambient conditions. Journal of Building Engineering, 44, 102612. doi:10.1016/j.jobe.2021.102612.

Emma Boghossiana, Leon D. Wegner. (2208). Use of flax fibres to reduce plastic shrinkage cracking in concrete. Cement and Concrete Composites, 30, 929-937. doi: 10.1016/j.cemconcomp.2008.09.003.

Page, J., Sonebi M., Amziane S. (2017). Design and multi-physical properties of a new hybrid hemp-flax composite material. Construction and Building Materials, 139(15), 502-512. doi:10.1016/j.conbuildmat.2016.12.037. 
П. В. Новосад, О. Р. Позняк

Національний університет “Львівська політехніка", кафедра будівельного виробництва

\section{ТЕПЛОІЗОЛЯЦЙНІ МАТЕРІАЛИ НА ОСНОВІ КОСТРИЦІ ЛЬОНУ}

(C) Новосад П. В., Позняк О. Р., 2021

Швидке зростання цін на енергоносії зумовлює пошук способів підвищення енергоефективності житлових та виробничих будівель і споруд, зокрема застосування сучасних теплоізоляційних матеріалів. Розроблення матеріалів на основі рослинної сировини допоможе вирішити проблеми, пов'язані з використанням сільськогосподарських відходів, і водночас отримати недорогі та ефективні теплоізоляційні матеріали на основі екологічно чистої місцевої сировини. Перевагами таких матеріалів є доступність, швидке відновлення, низька вартість, екологічність та низька теплопровідність разом 3 можливістю використання як органічних, так і неорганічних в'язких. Отримані матеріали задовольняють вимоги сталого розвитку, енергоефективності, економічної ефективності та екологічної сумісності. У роботі з використанням костриці льону за витрати портландцементу 150 кг на 1 м 3 бетону одержано теплоізоляційний легкий бетон з середньою густиною 350 кг/ $\mathrm{m}^{3}$ та міцністю 0,53 МПа. Одним із способів ефективного альтернативного теплозабезпечення є використання природних теплоізоляційних матеріалів у поєднанні з приймачами сонячного тепла, зокрема зі заскленим абсорбером. У статті представлено результати досліджень зміни температури на поверхні зовнішніх огороджувальних конструкцій $з$ використанням розробленого теплоізоляційного бетону на основі костриці льону в поєднанні з абсорбером сонячної енергії. Встановлено, що така конструкція зовнішньої стіни забезпечує теплову інерцію огородження протягом 7-7,5 год. Використання природного теплоізоляційного матеріалу з середньою густиною 350 кг/м³ дає змогу акумулювати сонячне тепло, чого неможливо досягти за використання традиційних синтетичних органічних теплоізоляційних мате-

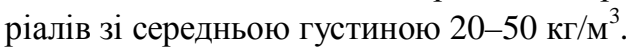

Ключові слова: енергоефективність, енергозбереження, костриця льону, теплоізоляційний бетон, адсорбер, теплова інерція. 